\title{
The relationship between soil, climate and forest development in the mid-mountain zone of the Sangong River watershed in the northern Tianshan Mountains, China
}

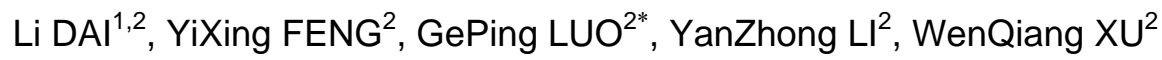 \\ ${ }^{1}$ School of Geographic and Environmental Sciences, Guizhou Normal University, Guiyang 550001, China; \\ ${ }^{2}$ State Key Laboratory of Desert and Oasis Ecology, Xinjiang Institute of Ecology and Geography, Chinese Academy of Sciences, \\ Urumqi 830011, China
}

\begin{abstract}
The mountainous forests in arid regions, being sensitive to climate change, are one of the key research topics related to the mechanism of interaction between climate and the terrestrial ecosystem. In this study, the spatial distribution of a mid-mountain forest and its environmental factors were investigated by using a combination of remote sensing technology, field survey, climate indices and soil nutrient analysis in the Sangong River watershed of the northern Tianshan Mountains. The forest (Picea schrenkiana) was distributed between 1,510 and 2,720 m asl. Tree height and diameter at breast height (DBH) exhibited a bi-modal pattern with increasing elevation, and rested at 2,450 and 2,250 m asl, respectively. The two maxima of DBH appeared at 2,000 and 2,550 $\mathrm{m}$ asl, and the taller trees were observed at 2,100 and 2,600 $\mathrm{m}$ asl. For the annual mean temperature, the difference was approximately $5.8^{\circ} \mathrm{C}$ between the lowest and the highest limits of the forest, and the average decreasing rates per hundred meters were $0.49^{\circ} \mathrm{C}$ and $0.55^{\circ} \mathrm{C}$ with increasing altitude between 1,500 and $2,000 \mathrm{~m}$ asl and above $2,000 \mathrm{~m}$ asl, respectively. The annual precipitation in the forest zone first increased and then decreased with the increase of altitude, and the maximum value was at $2,000 \mathrm{~m}$ asl. For per hundred meters, the annual precipitation increased with the rate of $31 \mathrm{~mm}$ between 1,500 and 2,000 $\mathrm{m}$ asl and decreased by $7.8 \mathrm{~mm}$ above 2,000 $\mathrm{m}$ asl. The SOM, TN and TP were high between 2,000 and 2,700 $\mathrm{m}$ asl and low at the lower and upper forest limits. The minimum $\mathrm{CaCO}_{3}$ concentration, $\mathrm{pH}$ value and EC coincided with the maximum precipitation belt at 2,000 $\mathrm{m}$ asl. The SOM, TN and TP were high in the topsoil $(0-10 \mathrm{~cm})$ and differed significantly from the values observed in the deep soil layers (>10 $\mathrm{cm}$ ). The soil nutrients exhibited spatial heterogeneity and higher aggregation in the topsoil. In conclusion, soil and climate are closely related to each other, working synergistically to determine the development and spatial distribution of the mid-mountain forest in the study area. The order of the importance of environmental factors to forest development in this study is as follows: soil nutrients>precipitation>elevation>temperature.
\end{abstract}

Keywords: mid-mountain forest; climatic conditions; soil properties; Picea schrenkiana; arid region; central Asia

\footnotetext{
Citation: Li DAI, YiXing FENG, GePing LUO, YanZhong LI, WenQiang XU. 2015. The relationship between soil, climate and forest development in the mid-mountain zone of the Sangong River watershed in the northern Tianshan Mountains, China. Journal of Arid Land, 7(1): 63-72. doi: 10.1007/s40333-014-0073-x
}

As one of the key components in the biosphere, forest plays an irreplaceable role in improving the environment and maintaining the balance of ecosystems, especially in fragile arid regions (Zhang, 1986; Zhao et al., 2003). Forest development and climate are clo- sely related. The climate in mountainous regions varies with increasing elevation, which causes spatial variation of the environmental factors and vertical vegetation zones. The dynamics of mountainous forests are obviously affected by climate change, especially at

\footnotetext{
*Corresponding author: GePing LUO (E-mail: luogp@ms.xjb.ac.cn) Received 2013-11-19; revised 2014-03-26; accepted 2014-04-18

(C) Xinjiang Institute of Ecology and Geography, Chinese Academy of Sciences, Science Press and Springer-Verlag Berlin Heidelberg 2015
} 
their lower and upper limits (i.e. treeline or timberline) (Scuderi, 1987). Alpine timberline is the transition zone from mountainous forest to grassland with few human activities. Alpine timberline is considered as a suitable indicator for climate change (Shi et al., 2000; Germino et al., 2002; Hoch et al., 2002; Körner and Paulsen, 2004; Wang et al., 2004; Shi et al., 2008; He et al., 2009). The diameter at breast height (DBH) and the tree height are usually used to indicate the status of forest development (Li, 1997). Therefore, the spatial distribution of these two indices reveals forest growth when the variation in space is not obvious.

Temperature and precipitation are considered as the main factors affecting the dynamics of mountainous forests, especially at the upper limit (Tranquillini, 1979; Fall, 1997). Extreme weather conditions, such as low temperature and drought, limit seed germination and seedling growth, and reduce the nutrient uptake abilities of plants (Chang and Sun, 1995; Chen et al., 2009). In an arid region, temperature and precipitation often have a combined impact on vegetation (Zhu et al., 2004; Peng et al., 2006; Sang et al., 2007). Soil is another limiting factor, as it provides nutrients for plant growth and influences vegetation via soil moisture and soil temperature (Luo, 1983; Chen et al., 2008). At the same time, plants return organic materials to the soil through litter. These factors change the soil structure, permeability and air capacity, all of which, in turn, influence the vegetation. However, few studies focus on the synergetic impact of both climate and soil on mountainous forests, especially in arid regions.

The temperature and precipitation in the arid central Asia have increased over the last 30 years (Nicholson, 2001; Shi et al., 2002; Qin et al., 2005; Chen et al., 2009), along with a great change in the vegetation structure (Zhang et al., 2003; Zhang et al., 2006). Both the lower and upper limits of Picea schrenkiana ( $P$. schrenkiana) have shifted upwards since the 1950s in this region (Zhang et al., 2003; Dai et al., 2013). Accordingly, exploring the relationship between soil properties, climate conditions and the spatial distribution of forests has an important significance for understanding and predicting forest dynamics under the conditions of climate change. This study explores a mid-mountain forest in the Sangong River watershed of arid central Asia and aims to (1) identify its spatial distribution pattern, (2) determine DBH and tree height at different elevations, (3) illustrate the local soil and weather conditions, and (4) analyze the control function of the environmental factors for the forest.

\section{Study area}

The Sangong River watershed $\left(43^{\circ} 09^{\prime}-45^{\circ} 29^{\prime} \mathrm{N}\right.$, $87^{\circ} 47^{\prime}-88^{\circ} 23^{\prime} \mathrm{E}$ ) is located in the northern Tianshan Mountains, Xinjiang, northwestern China (Fig. 1). The Tianshan Mountains extend across central Asia and are in one of the most arid mid-latitude zones in the world. The Tianshan Mountains are encircled by oases and deserts (Gurbantunggut Desert and Taklamakan Desert) in the adjacent plains and have dense forests in the mid-elevation zones along with permanent snow cover on high peaks.

The Sangong River watershed is low in the north and high in the south, with Bogda Peak and an alpine lake in the mountainous area $(\mathrm{Hu}, 2004)$. From 1979 to 2006 , in the mid-mountain zone $(1,600-2,700 \mathrm{~m}$ asl), the annual accumulated temperature $\left(\geq 10^{\circ} \mathrm{C}\right)$ was $2,100^{\circ} \mathrm{C}$, the annual mean temperature was $0.18^{\circ} \mathrm{C}$; the minimum and maximum temperatures were $-37^{\circ} \mathrm{C}$ and $33^{\circ} \mathrm{C}$, respectively; the annual precipitation was approximately $486.68 \mathrm{~mm}, 70 \%$ of which was rainfall; and the annual evaporation was approximately 1,339 $\mathrm{mm}$. The soil on the sunny slope of the mid-mountain zone is chernozem, which is covered by mountainous meadow (wild ryegrass, Bupleurum spp., Artemisia annua, etc.), with vegetation covers of $70 \%-90 \%$; grey cinnamon soil is on the shady slope beneath the mid-mountain forest. The constructive species of the mid-mountain forest is $P$. schrenkiana, which is the focus of this study. Grazing has been performed above the timberline and below the mid-mountain forest by the local Khazak herdsmen as their traditional way of living.

\section{Methods}

\subsection{Forest vegetation data}

A Quick Bird image of 2008 (June; cell size: $0.61 \mathrm{~m}$ ) and a SPOT image of 2009 (August; cell size: $2.50 \mathrm{~m}$ ) 


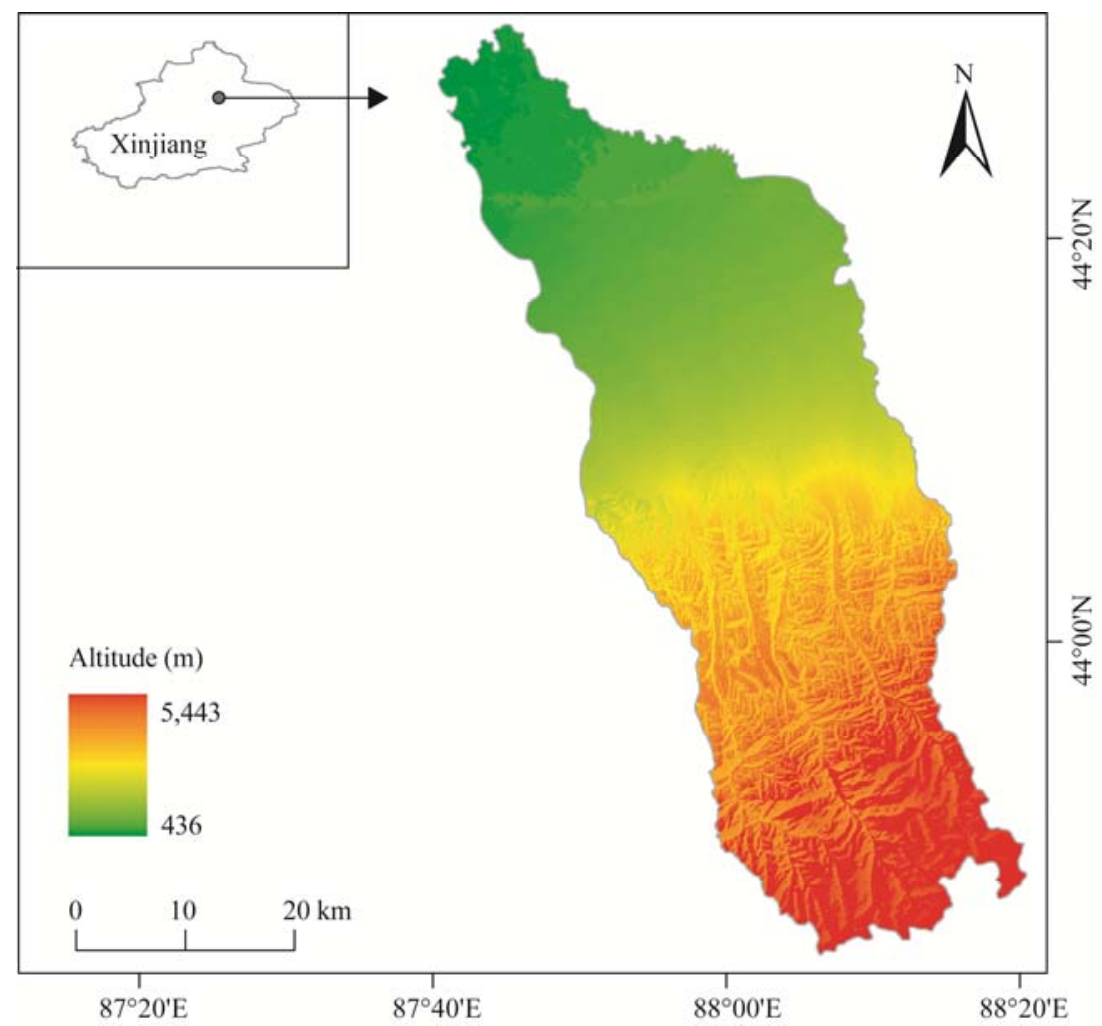

Fig. 1 The location of Sangong River watershed in Xinjiang, China

were orthorectified, geo-referenced, visually interpreted and classified. The distribution patterns of vegetation and the elevation belts of certain land cover types were obtained from remote sensing data, DEM (cell size: $30 \mathrm{~m}$ ) and topographic maps $(1: 50,000)$ (Njoku et al., 2003; Li et al., 2007).

In the summers of 2009 and 2010, fieldwork was conducted at the mid-mountain forest belt (1,500-2,700 m asl) of the Sangong River watershed. Six transects crossing the forest were randomly selected. For every two sampling plots chosen, there was a difference of at least $50 \mathrm{~m}$ in elevation along the transects. For each sampling plot $(30 \mathrm{~m} \times 30 \mathrm{~m})$, the GPS coordinates of the center and the species composition were recorded at field, and the altitude, aspect and slope were obtained from DEM according to the coordinates. Inside each plot, 10-12 trees (P. schrenkiana) were randomly selected for measurements of the tree height, DBH and crown width. The DBH and crown width were measured by using leather measuring tapes, and the tree height was measured with an altimeter. In total, 24 sampling plots and 252 trees were selected.

\subsection{Meteorological data}

Meteorological data were acquired from 13 mountainous weather stations inside or close to the Sangong River watershed, including the Tianchi meteorological station at $1,943 \mathrm{~m}$ asl, three automatic weather stations (near Tianchi station) at 1,065, 2,000 and 3,008 $\mathrm{m}$ asl, respectively, the Daxigou station at 3,539 $\mathrm{m}$ asl, and the Xiaoquzi station at 2,160 $\mathrm{m}$ asl. The data from the automatic weather stations spanned from 2003 to 2005, while the data from the others were from 1979 to 2009 .

The correlation of the air temperature and precipitation data (2003-2005) between the automatic and the other stations was analyzed. On the basis of the significant correlation $(P>0.98)$, DEM, the Inverse Distance Weighted (IDW) method and the MicroMet method (Liston and Elder, 2006), the monthly air temperature and precipitation were interpolated to cover the forest belt in the watershed from 1979 to 2006. The annual mean temperature, the mean temperature of January and July, and the annual precipitation were calculated at different elevation belts (Table 1). 
Table 1 Climate indices at different elevations in the mid-mountain forest zone of the Sangong River watershed

\begin{tabular}{cccc}
\hline $\begin{array}{c}\text { Elevation } \\
(\mathrm{m})\end{array}$ & $\begin{array}{c}\text { Annual mean } \\
\text { temperature }\left({ }^{\circ} \mathrm{C}\right)\end{array}$ & $\begin{array}{c}\text { Monthly mean temperature of } \\
\text { July }\left({ }^{\circ} \mathrm{C}\right)\end{array}$ & $\begin{array}{c}\text { Monthly mean temperature of } \\
\text { January }\left({ }^{\circ} \mathrm{C}\right)\end{array}$ \\
\hline 1,500 & 4.76 & 18.98 & -11.91 \\
2,000 & 2.82 & 15.06 & -11.75 \\
2,200 & 1.70 & 13.82 & -12.17 \\
2,600 & -0.54 & 11.34 & -13.01 \\
2,700 & -1.10 & 10.72 & -13.22 \\
\hline
\end{tabular}

\subsection{Soil sampling and processing}

Soil samples were collected in the summer of 2009. Four profiles were randomly selected at each of the six elevation belts (Table 2). At each profile, three soil samples were collected at three different depths (layer A: $0-10 \mathrm{~cm}$; layer B: $10-30 \mathrm{~cm}$; layer $\mathrm{C}:>30 \mathrm{~cm}$ ). The soil samples were air-dried, crushed and passed through a 2-mm sieve, and then the following properties were analyzed: the $\mathrm{pH}$ value was determined by using 1:1 soil/water mixture and soil- $\mathrm{KCl}$ solutions; the organic matter $(\mathrm{OM})$ was determined by using the Tyurin method; the total nitrogen (TN) was ascertained by the micro-Kjeldahl procedure after digestion with concentrated $\mathrm{H}_{2} \mathrm{SO}_{4}$ and measurement of $\mathrm{NH}_{3}$ by the indophenols blue method using an auto-analyzer; the total phosphorus (TP) was analyzed by using the $\mathrm{HClO}_{4}-\mathrm{H}_{2} \mathrm{SO}_{4}$ method; the $\mathrm{CaCO}_{3}$ concentration was determined by acid dissolution (pressure calcimeter method); and the electrical conductivity (EC) was determined by a saturated-paste method (Institute of Soil Sciences, Chinese Academy of Sciences, 1978). The soil property differences among the different layers and profiles at different elevation belts were analyzed by using one-way analysis of variance (ANOVA) and the $F$ test by SPSS 15.0. The relationship between soil, meteorological data and DBH was analyzed by using ANOVA. The $F$ values of all the soil variables (SOM, $\mathrm{TP}, \mathrm{TN}, \mathrm{EC}, \mathrm{pH}$ and $\mathrm{CaCO}_{3}$ ) were averaged to represent the impact of the soil properties.

\section{Results and discussion}

\subsection{Spatial distribution of $P$. schrenkiana forest}

With increasing elevation, $P$. schrenkiana changed gradually from small patches to closed forestland and finally to isolated trees. The lowest limit of $P$. schrenkiana patches ( $15 \%$ crown cover) in the Sangong River watershed was $1,510 \mathrm{~m}$ asl on the shady slope. Theses patches mixed with mountainous meadow. Closed forestland formed at approximately $1,620 \mathrm{~m}$ asl, where the size of the forest gap and the understory herbaceous coverage decreased and the soil moisture increased. At approximately $2,600 \mathrm{~m}$ asl, the forest density decreased with increasing shrub coverage. Above $2,720 \mathrm{~m}$ asl, there were mainly shrubby pine (Juniperus sabina) and meadows with few P. schrenkiana. Accordingly, the lowest and highest limits of forest in the watershed were in the ranges of

Table 2 Soil properties of the mid-mountain forest at different altitudes in the Sangong River watershed

\begin{tabular}{ccccccc}
\hline Elevation $(\mathrm{m})$ & $\mathrm{OM}(\%)$ & $\mathrm{TN}(\%)$ & $\mathrm{TP}(\%)$ & $\mathrm{CaCO}_{3}(\%)$ & $\mathrm{pH}$ & $\mathrm{EC}(\mathrm{ms} / \mathrm{cm})$ \\
\hline 1,527 & 4.50 & 0.13 & 0.065 & 7.21 & 8.04 & 0.16 \\
2,000 & 13.54 & 0.45 & 0.068 & 0.07 & 6.83 & 0.15 \\
2,301 & 10.49 & 0.37 & 0.065 & 3.42 & 7.36 & 0.22 \\
2,508 & 15.44 & 0.64 & 0.073 & 0.13 & 7.07 & 0.29 \\
2,701 & 17.97 & 0.61 & 0.077 & 0.14 & 7.33 & 0.31 \\
2,715 & 6.86 & 0.30 & 0.048 & 0.36 & 7.57 & 0.22 \\
Mean & 11.47 & 0.42 & 0.066 & 1.89 & 7.37 & 0.23 \\
\hline SD & 5.16 & 0.19 & 0.01 & 2.92 & 0.42 & 0.07 \\
CV & 0.45 & 0.47 & 0.15 & 1.54 & 0.06 & 0.31 \\
\hline
\end{tabular}


1,510 to $1,620 \mathrm{~m}$ and 2,600 to $2,720 \mathrm{~m}$ asl, respectively. The upper forest limit in the study area is close to the location of the alpine timberline on the northern slope of the Tianshan Mountains (Wang et al., 2004).

Both tree height and DBH were highly related to elevations $\left(R^{2}>0.7\right.$; Fig. 2). These relationships exhibited a "double-peak" pattern. The two maxima of DBH were at approximately 2,000 and 2,600 m, respectively. The highest trees were at $2,100 \mathrm{~m}$ asl, and a relatively small peak for tree height was at $2,650 \mathrm{~m}$ asl, which was at a slightly higher elevation than the larger DBH. The DBH and tree height decreased rapidly above $2,600 \mathrm{~m}$ asl, which is the transition zone of alpine timberline in the Sangong River watershed. This decrease indicates that the environment there has a negative impact on the growth of $P$. schrenkiana. However, a relatively large number of seedlings were found around the alpine timberline, which might be caused by a minimized environmental stress for $P$. schrenkiana seedlings compared with adult trees.

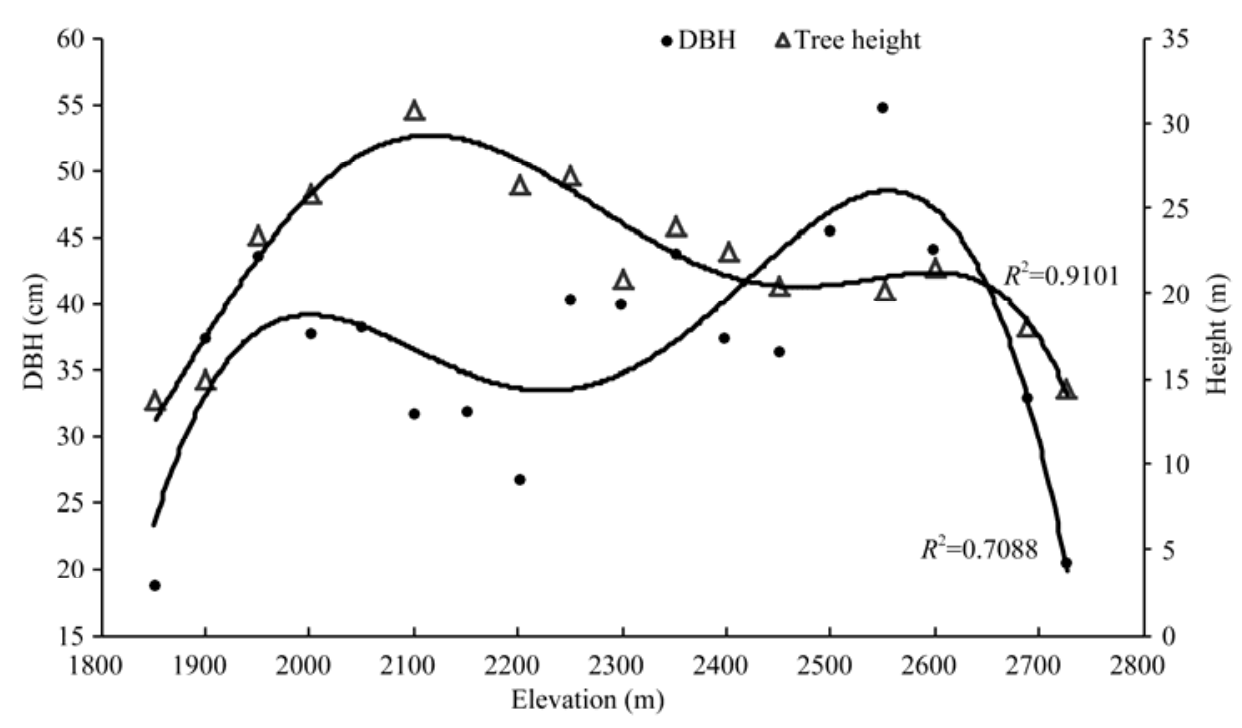

Fig. 2 The diameter at breast height $(\mathrm{DBH})$ and tree heights of $P$. schrenkiana at different altitudes in the Sangong River watershed

\subsection{Climate characteristics}

In terms of annual mean temperature, the difference between the lowest and highest limits of the forest was approximately $5.8^{\circ} \mathrm{C}$; the average decreasing rates per hundred meters were $0.49^{\circ} \mathrm{C}$ and $0.55^{\circ} \mathrm{C}$ with increasing altitude between 1,500 and 2,000 $\mathrm{m}$ asl and above $2,000 \mathrm{~m}$ asl, respectively. For the average temperature in the warmest month (July), the difference between the lowest and the highest limits of the forest was $8.3^{\circ} \mathrm{C}$. This value was higher than the annual mean temperature and lower than the average temperature in the coldest month (January). The mean temperature of January increased slightly from 1,500 to 2,000 m asl, but declined above 2,000 $\mathrm{m}$ asl (Table 1). The difference in the mean temperature of January between the two growing limits was $1.3^{\circ} \mathrm{C}$. This difference may be caused by the winter temperature inversions, which provides a less harsh condition in winter for the young trees and seedlings to grow near the timberline.

The annual precipitation within the forest zone first increased and then decreased with the increase of altitude, with the maximum at 2,000 $\mathrm{m}$ asl. For per hundred meters, the annual precipitation increased with the rate of $31 \mathrm{~mm}$ between 1,500 and 2,000 $\mathrm{m}$ asl and decreased by $7.8 \mathrm{~mm}$ above $2,000 \mathrm{~m}$ asl (Table 1). This typical precipitation pattern provides suitable moisture for forest growth in the mid-mountain zone. Compared with the climate in the mountainous forest of Xiaowutai Mountain (Yu et al., 2002), the annual mean temperature at all altitude belts in the Sangong River watershed is higher. This higher temperature may be caused by the reduced precipitation in the study area. At the upper limit of the mid-mountain forest, the mean temperature of January in the Sangong River watershed is $10^{\circ} \mathrm{C}$ higher than that of Xiaowutai Mountain (approximately $-23^{\circ} \mathrm{C}$ ) and is approximately $7^{\circ} \mathrm{C}$ lower than that of southeast Tibet 
$\left(-6.4^{\circ} \mathrm{C}\right)(\mathrm{He}$ et al., 2009). This temperature difference suggests that the mean temperature of the coldest month is not an environmental indicator limiting the growth of mountainous forests near the timberline in these three locations. In contrast, the mean temperature of the warmest month at the upper forest limit is similar to that of Xiaowutai Mountain $\left(10.8^{\circ} \mathrm{C}\right)$ and is slightly higher than that of southeast Tibet $\left(9.4^{\circ} \mathrm{C}\right)$, with the average value within that of China $\left(9.7^{\circ} \mathrm{C}\right)$ (Wang et al., 2004), the Alps and the Rocky Mountain region $\left(10^{\circ} \mathrm{C}\right)$ (Tranquillini, 1979; Grace, 1987; Scuderi, 1987). This may be because that the Sangong River watershed is inside an arid zone with less precipitation and a low heat capacity, which leads to a rapid increase in temperature during summer.

\subsection{Soil properties}

The mean and standard deviation of the soil properties (SOM, TN, TP, $\mathrm{CaCO}_{3}, \mathrm{pH}$ and $\mathrm{EC}$ ) at different elevation belts are presented in Table 2 . The distribution patterns of SOM and TN were the same: initially positively correlated and then negatively related with altitude changes; low at the upper and lower limits of the forest zone, and high in the middle elevation belt. The SOM and TN at the upper limit of the P. schrenkiana forest $(2,701$ and $2,715 \mathrm{~m}$ asl $)$ in the study area were $12.41 \%$ and $0.46 \%$, respectively, which were slightly higher than the mean values in the entire forest zone ( $11.47 \%$ for SOM and $0.42 \%$ for TN). TP was $0.063 \%$ at the upper limit, which is similar to the value in the entire forest zone $(0.066 \%)$. However, the SOM, TP and $\mathrm{TN}$ at the upper limit were significantly different from the values in the alluvial plain of the adjacent oasis inside the Sangong River watershed $(P<0.05)$ (Luo et al., 2005).

The $\mathrm{SOM}$ reached a maximum at $2,700 \mathrm{~m}$ asl, which was mainly due to its low decomposition rate. The ideal temperature for soil microbial activity is within the range of $25^{\circ} \mathrm{C}-35^{\circ} \mathrm{C}$ (Zhang, 1986). However, temperature decreases rapidly with increasing altitude, and the annual mean temperature is below $0^{\circ} \mathrm{C}$ in the mountainous forest of the Sangong River watershed (Table 1). The low temperature inhibits the activities of a variety of microbial enzymes, which results in the accelerated accumulation of SOM at certain elevation belts. At $2,715 \mathrm{~m}$ asl (close to the timberline), the SOM was much lower compared with the values for the closed forest $(2,000-2,500 \mathrm{~m}$ asl), which may be caused by the enhanced rate of organic matter decomposition. The lower crown cover and the growth of herbaceous plants near the timberline increase the soil temperature and the soil microbial activity. The SOM and TN were low at the lower limit of the forest, which may be caused by the limited vegetation growth due to the low precipitation there. In addition, the high annual mean temperature leads to intense microbial activity and a rapid litter decomposition rate, which has a negative impact on the SOM and TN accumulation.

Except at the elevations of 2,301 and 1,527 m asl, the $\mathrm{CaCO}_{3}$ concentration was positively related to elevation within the forest belt. The lowest value was at 2,000 $\mathrm{m}$ asl, which coincided with the maximum annual precipitation (Table 1). At this elevation, litter forms humus and acidic, and water infiltration occurs in the dark and humid coniferous forest, which results in the decomposition of soil minerals and the leaching of $\mathrm{Ca}^{2+}$ into deeper soil layers. The high standard deviations of $\mathrm{SOM}$ and $\mathrm{CaCO}_{3}$ concentrations indicated that the distribution of these two soil properties were spatially heterogeneous. The soil $\mathrm{pH}$ values at the upper and lower limits of the forest were higher than those inside the forest. At $1,527 \mathrm{~m}$ asl, the $\mathrm{pH}$ reached 8.04 , the most alkaline level in the study area. In contrast with the neutrality and alkalinity at the other locations, the soil was slightly acidic at $2,000 \mathrm{~m}$ asl $(\mathrm{pH}=6.83)$. This acidity may be related to the high precipitation at this altitude: abundant rainfall results in leaching, migration of metal ions into deeper soil, excess $\mathrm{H}^{+}$and eluviations of the soil and parent materials. These processes enhance the combination of soil with $\mathrm{H}^{+}$and thus increase the acidity (Huang, 2008). Except at the elevations of 2,715 and 1,527 $\mathrm{m}$ asl, the EC gradually increased with the increase of altitude. The lowest $\mathrm{EC}$ was at 2,000 $\mathrm{m}$ asl (similar to $\mathrm{pH}$ and $\mathrm{CaCO}_{3}$ ), which may be caused by the decreasing base saturation under the rich precipitation.

The soil properties at different depths and altitudes in the Sangong River watershed are shown in Fig. 3. In layer A $(0-10 \mathrm{~cm}), \mathrm{SOM}$ and $\mathrm{TN}$ exhibited an increasing-stable-decreasing trend with increasing altitude. The values of both soil SOM and TN were high within the elevation range of 2,600-2,700 $\mathrm{m}$ asl and 
then declined. In contrast with SOM, the TN in the topsoil $(0-10 \mathrm{~cm})$ was lower at the lower limit of the forest than at the upper limit. The TP in the topsoil reached its maximum at $2,000 \mathrm{~m}$ asl, and then decreased gradually above this altitude. The TP of layer $\mathrm{B}$ was higher at $2,500-2,700 \mathrm{~m}$ asl, close to that of layer A. Although the trends of SOM and TN values in all three layers were similar, these two properties, as well as the TP, of layer $\mathrm{A}$ and $\mathrm{B}$ were significantly different $(P<0.05$; Table 3$)$. The $\mathrm{CaCO}_{3}$ concentration, $\mathrm{pH}$ and EC exhibited no significant difference between layers $\mathrm{A}$ and $\mathrm{B}$. The $\mathrm{EC}$ of layer $\mathrm{C}$ was approximately $0.1 \mathrm{mS} / \mathrm{cm}$, with low spatial variation, and differed from that of the other layers $(P<0.1)$. The differences in $\mathrm{CaCO}_{3}$ concentration, $\mathrm{pH}$ and $\mathrm{EC}$ within each layer were not significant.

The SOM, TN and TP in all three layers at 2,700 m asl were higher than those at other elevation belts and then decreased with increasing altitudes. The SOM, TN and TP were higher in the topsoil $(0-10 \mathrm{~cm})$ and decreased with increasing soil depths, which suggested a phenomenon of soil surface convergence due to topsoil enrichment by decomposing litter accumulated at the soil surface. The SOM, TN and TP were enriched in layer A through the processes of decomposition and conversion. These enrichment processes are similar to those at the timberlines of the northern Tianshan Mountains (Dai et al., 2013) and

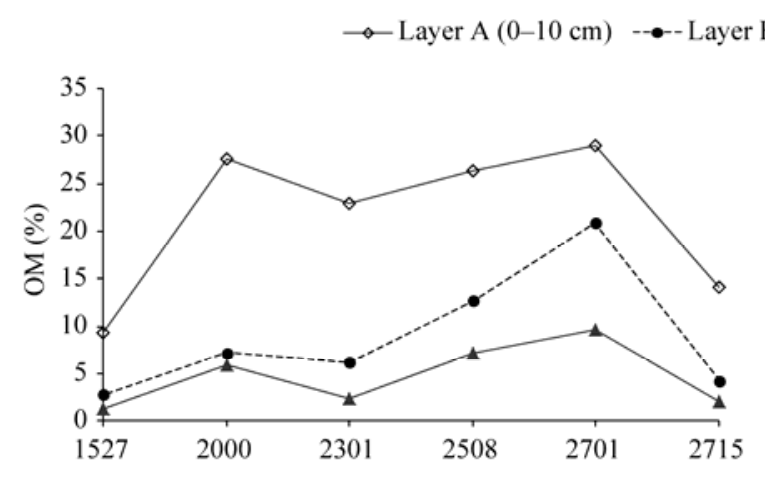

$(10-30 \mathrm{~cm}) \rightarrow$ Layer $\mathrm{C}(>30 \mathrm{~cm})$
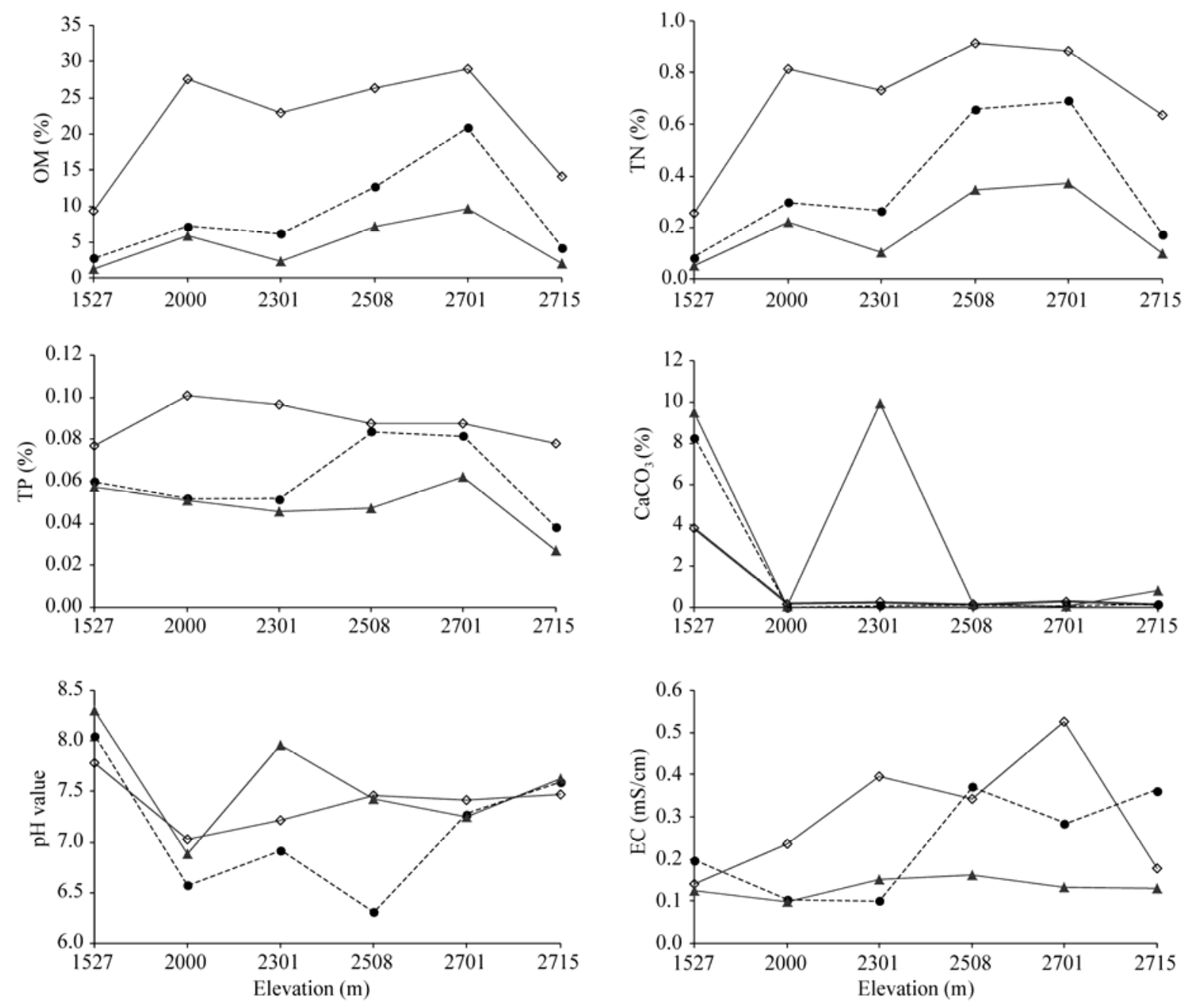

Fig. 3 Soil properties of different depths at different altitudes in the Sangong River watershed 
Table 3 Soil properties at different depths in the mid-mountain forest soil of the Sangong River watershed

\begin{tabular}{ccccccc}
\hline & OM $(\%)$ & $\mathrm{TN}(\%)$ & $\mathrm{TP}(\%)$ & $\mathrm{CaCO}_{3}(\%)$ & $\mathrm{pH}$ & $\mathrm{EC}(\mathrm{mS} / \mathrm{cm})$ \\
\hline Layer A & $21.54^{\mathrm{a}}$ & $0.71^{\mathrm{a}}$ & $0.088^{\mathrm{a}}$ & $0.79^{\mathrm{a}}$ & $7.40^{\mathrm{a}}$ & $0.30^{\mathrm{a}}$ \\
Layer B & $8.08^{\mathrm{b}}$ & $0.34^{\mathrm{b}}$ & $0.061^{\mathrm{b}}$ & $1.45^{\mathrm{a}}$ & $7.13^{\mathrm{a}}$ & $0.24^{\mathrm{a}}$ \\
Layer C & $4.78^{\mathrm{b}}$ & $0.20^{\mathrm{b}}$ & $0.046^{\mathrm{b}}$ & $3.42^{\mathrm{a}}$ & $7.58^{\mathrm{a}}$ & $0.13^{\mathrm{b}}$ \\
Mean & 11.47 & 0.42 & 0.066 & 1.89 & 7.37 & 0.22 \\
\hline SD & 9.21 & 0.29 & 0.021 & 3.51 & 0.5 & 0.13 \\
CV & 0.80 & 0.69 & 0.32 & 1.86 & 0.07 & 0.59 \\
$F$ value & 14.32 & 9.50 & 12.96 & 0.90 & 1.23 & 3.66 \\
$P$ value & 0.000 & 0.002 & 0.001 & 0.429 & 0.319 & 0.051 \\
\hline
\end{tabular}

Note: The lowercase letters following the numeric value within the same column represent the difference between the soil layers: if the letters are the same, there is no difference; if the letters are different, the difference is significant. SD, standard deviation; $C V$, coefficient of variation. The $F$ and $P$ values indicate the significant difference between the three layers.

also explain the weakening of spatial heterogeneity of the three soil parameters within the same layer in deeper soil.

The $\mathrm{CaCO}_{3}$ concentration of all soil layers at the lower limit of the forest was higher than that at the other parts, and was lower above $2,000 \mathrm{~m}$ asl. This observation coincides with the rich precipitation in the forest, which leads to $\mathrm{Ca}^{2+}$ leaching. The abnormal high $\mathrm{CaCO}_{3}$ concentration in layer $\mathrm{C}$ at $2,301 \mathrm{~m}$ asl may be influenced by the $\mathrm{Ca}^{2+}$ accumulation at certain depths. The slight increase of the $\mathrm{CaCO}_{3}$ concentration of layer $\mathrm{C}$ at the upper limit of the forest may be due to the reduced precipitation there. In addition, shrubby pine and herbs at this elevation have lower capacities of fixing minerals in the roots compared with forest trees, which also leads to $\mathrm{Ca}^{2+}$ leaching into deeper soil (Huang, 2008).

\subsection{Effect of environmental factors on $P$. schr- enkiana development}

The results of the one-way ANOVA analysis between the DBH and environmental factors are presented in Table 4. The soil properties exhibited the most significant influence on the DBH of P. schrenkiana, followed by precipitation and elevation. On the contrary, the annual mean temperature exhibited little impact on the DBH. Except for $\mathrm{TN}$ and $\mathrm{CaCO}_{3}$, the other soil properties affected the DBH significantly $(P<0.05)$, with SOM, $\mathrm{pH}$ and TP having the stronger impact $(P<0.01)$. By averaging all of the $F$ values related to the soil (SOM, TP, TN, $\mathrm{EC}, \mathrm{pH}$ and $\mathrm{CaCO}_{3}$ ), the mean $F$ value of the soil properties was 6.608 , which was higher than the mean $F$ values of both elevation and meteorological data. Therefore, the order of importance of all of the factors in Table 4 to the DBH of the mid-mountain forest is as follows: soil nutrients $>$ precipitation $>$ elevation $>$ temperature. This relationship indicates that soil nutrients are the key environmental factors limiting the development of the mid-mountain forest in the Sangong River watershed in the northern Tianshan Mountains, which is similar to the results of other studies (Qi et al., 2004; Dai et al., 2013). However, the influence of climatic factors (precipitation>temperature) in this study differs from the temperature-controlling mechanism (temperature $>$ precipitation) at some timberlines of Chinese mountains (Wang et al., 2004). This difference may be caused by the differences of study areas (arid region vs. humid region), research objects (mid-mountain forest vs. timberline) and microclimates.

Table 4 One-way ANOVA analysis between the DBH of $P$. schrenkiana and environmental factors

\begin{tabular}{ccccccccccc}
\hline & Elevation & $\begin{array}{c}\text { Annual mean } \\
\text { temperature }\end{array}$ & $\begin{array}{c}\text { Annual } \\
\text { precipitation }\end{array}$ & $\mathrm{OM}$ & $\mathrm{TN}$ & $\mathrm{TP}$ & $\mathrm{CaCO}_{3}$ & $\mathrm{pH}$ & $\mathrm{EC}$ \\
\hline$F$ value & 4.799 & 1.900 & 5.633 & 6.115 & 2.127 & 11.318 & 3.557 & 11.658 & 4.874 \\
$P$ value & 0.006 & 0.184 & 0.003 & 0.009 & 0.150 & 0.001 & 0.073 & 0.003 & 0.019 \\
\hline
\end{tabular}




\section{Conclusions}

The relationships between environmental factors and the development of the mid-mountain forest were explored in the Sangong River watershed by using a combined method of field survey, remote sensing and meteorological observation. The forest is distributed between 1,510 and $2,720 \mathrm{~m}$ asl. The tree height and DBH exhibited a bi-modal pattern with increasing elevation, and rested at 2,450 and 2,250 m asl, respectively. The SOM, TN and TP were high between 2,000 and 2,700 $\mathrm{m}$ asl and were low at the lower and upper forest limits. The minimum values of $\mathrm{CaCO}_{3}$ concentration, $\mathrm{pH}$ and EC coincided with the maximum precipitation belt at 2,000 m asl. The SOM, TN and TP were high in the topsoil $(0-10 \mathrm{~cm})$ and were significantly different from those in the deep layers $(>10 \mathrm{~cm})$. The soil nutrients exhibited spatial heterogeneity and higher aggregation in the topsoil. In conclusion, soil properties and climate are closely related to each other, working synergistically to determine the development and spatial distribution of the mid-mountain forest in the study area. Studies combining timberline and lower limit of the forest with environmental factors are recommended for further understanding the vegetation development in the mountains of arid regions.

\section{Acknowledgements}

This study was funded by the National Natural Science Foundation of China (41271126), the Ph.D. Research Foundation of Guizhou Normal University and the Science and Technology Foundation of Guizhou Province (J[2014]2126).

\section{References}

Chang Z H, Sun J K. 1995. Forest Soil of Xinjiang Mountain Region. Urumqi: Xinjiang Health Science and Technology Publishing House. (in Chinese)

Chen S Y, Guo J Y, Han T, et al. 2009. Climate warming of autumn air temperature in arid and semiarid regions in Northwest China over the recent 46 years. Journal of Desert Research, 29(3): 544-550. (in Chinese)

Chen X, Xu W Q, Luo G P, et al. 2008. Soil properties at the tree limits of Picea schrenkiana forests in response to varying environmental conditions on the northern slope of Tianshan mountains. Acta Ecologica Sinica, 28(1): 53-61. (in Chinese)

Dai L, Li Y Z, Luo G P, et al. 2013. The spatial variation of alpine timberlines and their biogeographical characteristics in the northern Tianshan Mountains of China. Environmental Earth Sciences, 68(1): 129-137.

Fall P L. 1997. Timber fluctuation and late Quaternary paleoclimates in the Southern Rocky Mountains, Colorado. Geological Society of America Bulletin, 109(10): 1306-1320.

Germino M J, Smith W K, Resor A C. 2002. Conifer seedling distribution and survival in an alpine-treeline ecotone. Plant Ecology, 162: $157-168$.

Grace J. 1987. Climatic tolerance and the distribution of plants. New Phytologist, 106(suppl.): 113-130.

He J C, Luo T X, Xu Y Q. 2009. Characteristics of eco-climate at smith fir timberline in the Sergyemla Mountains, Southeast Tibetan Plateau. Acta Ecologica Sinica, 29(1): 37-46. (in Chinese)

Hoch G, Popp M, Körner C H. 2002. Altitudinal increase of mobile carbon pools in Pinus cembra suggests sink limitation of growth at the Swiss treeline. Oikos, 98(2): 361-374.

Hu R J. 2004. The Physical Geography of Tianshan Mountains in China. Beijing: China Environment Science Publishing House. (in Chinese)

Huang C Y. 2008. Pedology. Beijing: China Agriculture Press. (in Chinese)

Institute of Soil Sciences, Chinese Academy of Sciences. 1978. Analysis of Soil Physics and Chemistry. Shanghai: Shanghai Science and Technology Press. (in Chinese)

Körner C, Paulsen J. 2004. A world-wide study of high altitude treeline temperatures. Journal of Biogeography, 31(5): 713-732.

Li X, Huang C L, Che T, et al. 2007. Development of a Chinese land data assimilation system: its progress and prospects. Progress in Natural Science, 17(2): 163-173.

Li Y D. 1997. Community Characteristics of Tropical Mountain Rain Forest in Jianfengling, Hainan Island. Journal of Tropical and Subtropical Botany, 5(1): 18-26. (in Chinese)

Liston G E, Elder K. 2006. A meteorological distribution system for high-resolution terrestrial modeling (MicroMet). Journal of Hydrometeorology, 7(2): 217-234.

Luo G P, Xu W Q, Chen X. 2005. Effect of different land-use systems on soil properties in the Alluvial Plain-oasis in the Arid Land. Acta Geographica Sinica, 60(5): 779-790. (in Chinese)

Luo R Y. 1983. Forest Soil Science (Problems and Methods). Beijing: Science Press. (in Chinese)

Nicholson S E 2001. Application of remote sensing to climatic and environmental studies in arid and semi-arid lands. Geoscience and Remote Sensing Symposium, IGARSS '01. IEEE 2001 International, 3: 985-987.

Njoku E G, Jackson T J, Lakshmi V, et al. 2003. Soil moisture retrieval from AMSR-E. IEEE Transactions on Geoscience and Remote Sensing, 41(2): 215-329.

Peng J F, Gou X H, Chen F H, et al. 2006. The responses of growth ring width variations of Larix sibirica Ledb to climatic change in eastern Tianshan Mountains. Acta Ecologica Sinica, 26(8): 2723-2731. (in Chinese)

Qi Z M, Wang K Y, Song G Y, et al. 2004. Bio-chemical properties of the forest floor in subalpine bamboo communities in western Sichuan. Acta Ecologica Sinica, 24(6): 1230-1236. (in Chinese) 
Qin D H, Ding Y H, Su J L, et al. 2005. Assessment of climate and environment changes in China (I): climate and environment changes in China and their projection. Advances in Climate Change Research, 1(1): 4-9. (in Chinese)

Sang W G, Wang Y X Su H X, et al. 2007. Response of tree-ring width to rainfall gradient along the Tianshan Mountains of northwestern China. Chinese Science Bulletin, 52(21): 2954-2962.

Scuderi L A. 1987. Late-Holocene upper timberline variation in the southern Sierra Nevada. Nature, 325: 242-244.

Shi P, Körner C H, Hoch G. 2008. A test of the growth-limitation theory for alpine tree line formation in evergreen and deciduous taxa of the eastern Himalayas. Functional Ecology, 22: 213-220.

Shi P L, Li W H, Wang J X, et al. 2000. Species-abundance relation of herb communities in subalpine timber-line ecotone of Wolong Natural Reserve, Sichuan Province, China. Acta Ecologica Sinica, 20(5): 384-389. (in Chinese)

Shi Y F, Shen Y P, Hu R J. 2002. Preliminary study on signal, impact and foreground of climatic shift from warm-dry to warm-humid in Northewest China. Journal of Glaciology and Geocryology, 24(3): 219-226. (in Chinese)

Tranquillini W. 1979. Physiological Ecology of Alpine Timberline.
Berlin: Springe-Verlag.

Wang X P, Zhang L, Fang J Y. 2004. Geographical Differences in Alpine Timberline and Its Climatic Interpretation in China. Acta Geographica Sinica. 59(6): 871-879. (in Chinese)

Yu P T, Liu H Y, Cui H T. 2002. Vegetation and its relation with climate conditions near the timberline of Beitai, the Xiaowutai Mts., northern China. Chinese Journal of Applied Ecology, 13(5): 523-528. (in Chinese)

Zhang B P, Zhou C H, Chen X P. 2003. The geo-info-spectrum of montane altitudinal belts in China. Acta Geographica Sinica, 58(2): 163-171. (in Chinese)

Zhang W R. 1986. China Forest Soil. Beijing: Science Press. (in Chinese)

Zhang Y, Kong Z C, Yan S, et al. 2006. Fluctuation of Picea timberline and paleo-environment on the northern slope of Tianshan Mountains during the Late Holocene. Chinese Science Bulletin, 51(14): 1747-1756.

Zhao C Y, Feng Z D, Liu Y. 2003. Study on one of ecological services of forest ecosystem in arid region water resource conservation. Journal of Mountain Science, 21(2): 157-161. (in Chinese)

Zhu H F, Wang L L, Shao X M, et al. 2004. Tree ring-width response of Picea schrenkiana to climate change. Acta Geographica Sinica, 59(6): 863-870. (in Chinese) 